\title{
INTRODUCTION
}

\author{
Mervi Rajahonka, Dorota Kwiatkowska- \\ Ciotucha, Miet Timmers, Urszula Załuska \\ and Kaija Villman
}

\begin{abstract}
People with a dual care task at home, taking care of a younger and an older generation family member, are often called the sandwich generation (SG). They are more often women than men, at high risk of burnout or withdrawal from the labour market. This book provides international comparisons and offers tools for working sandwich generation (WSG) women and their supervisors for managing challenging situations in working life. The book is multidisciplinary and combines theories with qualitative and quantitative empirical research, practical tools and case studies. This chapter introduces the themes and relevant concepts of the book and presents its structure.
\end{abstract}

\section{SANDWICH GENERATION}

Although there are different definitions for the sandwich generation (SG), it is usually referred to as

individuals or couples within the age group 45 to 65 who, in addition to their work activities, also take care of their own (young or growing up) children together with the care of their ageing parents. (Bronselaer, 2016)

Another definition states that 'the sandwich generation refers to individuals who, by dint of circumstances, find themselves in the position of being caregivers for their young children, and/or adult children and care for one 
or both of aging parents' (Chisholm, 1999, p. 178), whereby the working sandwich generation (WSG) is squeezed between the needs of children, parents and workplaces (Burke, 2017, p. 3). The traditional sandwich analogy is taken even further by some authors, creating terms such as the club sandwich to denote the group of people who care for their grandchildren and an older generation and the panini sandwich for people who care for an (adult) child with a disability and member of an older generation (Abramson, 2015). In other words, the SG has a dual care task at home caring for an older and a younger generation at the same time.

The concept of the SG was introduced in by Dorothy Miller (1981) to portray women in their 30s to 40s who were caring for their young children and ageing parents. Nowadays, the SG has become older, the largest age group being older than 40 years, and the definition includes both genders, as men can also have dual care tasks. Further, before, the biggest group of people belonging to the SG were Baby boomers, but after that Generation X, and soon the Millennials will take over (Parker \& Patton, 2013).

It is obvious that due to demographic trends and longer working lives, the number of people in the sandwich position is expected to rise. There are several reasons to assume that the WSG will grow in the future. People delay childbearing, children stay at home longer and the older generation is living for longer. With governments facing challenges in the presence of ageing populations, public policies in many countries are offering fewer care home places to the older generation, leading to the older generation living in their own homes for longer. At the same time, SG people retire later and work for longer. Various policy measures such as pension reforms in European countries are resulting in more people over the age of 50 remaining in the labour market. This means that the number of SG people who still are working is increasing, too.

The gender gap (men working longer) of older workers in employment is narrowing in some countries, although it remains robust in others (European Commission, 2020; Zamarro, 2020). Where in 2000 in EU27 48.8\% of the male population between 55 and 64 years was working compared to $27.8 \%$ of women, the employment rate had risen to $69.6 \%$ for men and $55.4 \%$ for women by 2019. Participation in the workforce by older workers is expected to keep increasing substantially for most countries to an average of $72 \%$ in 2070. Even for people between 64 and 74 years of age, projections foresee an employment rate of up to $20 \%$ in 2070 (European Commission, 2020). This can indicate that in the future more grandparents will be participating in the workforce. Zamarro (2020) suggests that workers who are grandmothers, therefore familiar with the challenges of balancing work and care 
responsibilities, are more willing to provide grandchild care, thus putting themselves often willingly in a sandwich position.

There is a clear gender aspect interwoven with the sandwich position: it is much more often women than men who take care of their ageing relatives, while women also more often take care of their own children and grandchildren. For these reasons, this book focusses especially on women between 45 and 65 years of age combining a full-time or part-time job or independent activity with a dual care task at home. This group is at high risk of burnout or withdrawal from the labour market. We provide international comparisons and offer tools for the WSG and their supervisors, educators and coaches for managing challenging situations in working life.

\section{THE BOOK IS CREATED IN TRANSNATIONAL COOPERATION}

The book is based on transnational cooperation between researchers from Flanders (the Dutch-speaking part of Belgium), Poland and Finland. The Time4Help project, under which a Polish-Finnish-Flemish partnership was established, has emphasised the issues of SG in these countries to a different extent. Thus, in Poland, the target group of the project was mature women, aged 45-65, whereas the research that was carried out concerned the situation of that group in the labour market. In Finland, the most important aspect was mature women's entrepreneurship, which means that women are also the target group of the project in this country. However, in Flanders the keynote topic is the SG, and therefore the target group included both male and female participants.

The three countries indicated in the book and represented in the transnational Time4Help project differ greatly in many aspects, illustrating the varied circumstances of SG women across Europe, which makes the analyses carried out extremely interesting and valuable for both practitioners and researchers.

Several factors have been discussed in earlier research that affect intergenerational support within families. These range from 'welfare state generosity' or national and local policies and institutions to family structures, family policies and systems of social care provision, values and traditions concerning families and the education balance between generations and sexes (Albertini, 2016).

There are also several relevant variables differentiating Poland, Finland and Flanders, including: (1) financial and economic aspects, as Poland is a country from the former Eastern bloc characterised by a lower standard of living (measured e.g. by gross domestic product (GDP) per capita) and a 
lower level of working conditions than Belgium and Finland, related to wellbeing at work, burnout, etc. (2) Political aspects, where, for example, welfare state regimes, and women's rights are quite different. Differences in welfare state regimes, Finland with a Scandinavian Social democratic model, Belgium with a Continental conservative model and Poland with the Central and Eastern European model (Ebbinghaus, 2012; Eikemo, Bambra, Joyce, \& Dahl, 2008; Emigh, Feliciano, O’Malley, \& Cook-Martín, 2018; EspingAndersen, 1990), have an impact on, among other things, how wellbeing at work is understood in society - is it a private issue or a social issue (OllierMalaterre, 2017; Silverstein, Tur-Sinai, \& Lewin-Epstein, 2020). (3) Cultural aspects, as the three countries differ significantly in terms of their cultural dimensions, for example, in their prevailing perceptions considering gender roles, individualism and religion (Gesteland, 1999; Hofstede, 1980; Hofstede, Hofstede, \& Minkov, 2010; House, Hanges, Javidan, Dorfman, \& Gupta, 2004; Schwartz, 2012). (4) Women's labour market participation, being $63.6 \%$ in Poland, $64.5 \%$ in Belgium and 76.6\% in Finland in 2016 (OECD LSF Indicators by sex). Some more comparisons are presented in Table 1.

Since during the project implementation we noticed a great need for international comparative research on SG, we jointly developed a research formula for comparing people aged 45-65 in five European countries.

Due to our transnational multidisciplinary research cooperation and by combining quantitative and qualitative data, we can present extensive analyses of the situation of women and men in the labour market in countries that differ in terms of the solutions adopted, and from the individuals' perspective as well as the employers' and policy-makers' perspective. While designing and carrying out research, we use four types of triangulation: (1) data triangulation, combining current field research with previous studies, (2) investigator triangulation in multidisciplinary teams of researchers from different countries, (3) theory triangulation, using the interpretive and positivist paradigms in the analysis, and (4) methodological triangulation, namely using various methods of qualitative and quantitative data analysis (Denzin \& Lincoln, 2018).

\section{STRUCTURE OF THE BOOK}

The book is structured in four parts where Part A describes the theoretical and empirical work done in Flanders, Poland and Finland, Part B presents tools developed in the national projects and case studies from the projects, Part $\mathrm{C}$ introduces the international comparative study of the SG in five European 
Table 1. Some Comparisons of the Three Countries (BBC News, 2020; Deloitte, 2017; Eurostat, 2021).

\begin{tabular}{|c|c|c|c|}
\hline & Belgium & Finland & Poland \\
\hline Population 2020 & 11.5 million & 5.5 million & 38.0 million \\
\hline GDP per capita 2020 & 33,560 EUR & 36,070 EUR & 12,680 EUR \\
\hline Life expectancy 2019 & $\begin{array}{l}84.3 \text { female; } 79.8 \\
\text { male }\end{array}$ & $\begin{array}{l}84.8 \text { female; } 79.3 \\
\text { male }\end{array}$ & $\begin{array}{l}81.9 \text { female; } 74.1 \\
\text { male }\end{array}$ \\
\hline $\begin{array}{l}\text { Proportion of part-time } \\
\text { employment and temporary } \\
\text { contracts (men/women) } \\
2020\end{array}$ & $9.9 \% / 39.6 \%$ & $9.1 \% / 17.9 \%$ & $3.2 \% / 8.8 \%$ \\
\hline $\begin{array}{l}\text { Average hourly earnings for } \\
\text { women lower than those for } \\
\text { men } 2019\end{array}$ & $5.8 \%$ & $16.6 \%$ & $8.5 \%$ \\
\hline $\begin{array}{l}\text { Adults (aged } 16-74 \text { years) } \\
\text { used the Internet during the } \\
\text { previous three months } 2020\end{array}$ & $92 \%$ & $97 \%$ & $83 \%$ \\
\hline $\begin{array}{l}\text { Fertility rate per woman } \\
2019\end{array}$ & 1.58 & 1.35 & 1.44 \\
\hline Maternal leave & 3.75 months & 4.4 months & 5 months \\
\hline Parental leave & 4 months & 6 months & 8 months \\
\hline Paternity leave & 10 days & 2.2 months & 15 days \\
\hline
\end{tabular}

countries based on the transnational cooperation and Part D presents discussion, conclusions and recommendations for employers and policy-makers on how to support people of SG.

In the first part of the book, we present evidence-based material to support women in working life from three angles: (1) coping strategies to enable the combination of a dual care task with a job, (2) improvement of competences of working mature women and (3) lifelong learning as means to support women's sustainable careers. After this introduction, Miet Timmers and Veerle Lengeler in their chapter 'How Do They Manage? Coping Strategies of the Working Sandwich Generation in Flanders' study different coping mechanisms people use to deal with stress. Some of the strategies are more effective than others. Based on qualitative research in Flanders, this chapter presents a new taxonomy of nine coping strategies that WSG members use to cope with the demands of different life domains and different roles.

Next, the Polish researchers Dorota Kwiatkowska-Ciotucha and Urszula Załuska discuss various themes based on their extensive research in their chapter ' $45+$ Polish Women at Home and in the Labour Markets'. Firstly, based on their semiotic research, they discuss the mechanisms and symbolism 
of mature femininity in Polish popular culture and public discourse. Secondly, they discuss the findings of their computer-assisted telephone interviews (CATI) research, indicating that in Poland, taking care of other people is an important barrier to the employment of mature women. The objects of interest of the CATI research were two groups: employers and mature women the study was therefore, conducted on a nationwide representative sample of mature women $(N=1,000)$ and a sample of employers $(N=100)$. The results show that there are similarities and differences in the opinions of mature women and their employers.

The chapter 'Sandwich Generation Women in Search for Meaningful Work and Life' by the Finnish researchers Mervi Rajahonka and Kaija Villman discuss opportunities for lifelong learning as means of supporting SG women. They studied female managers and entrepreneurs and their views on lifelong learning. The particular focus is on how learning relates to these women's careers, wellbeing at work and search for meaningful lives. In the chapter, a new model integrating women's earning, learning and meaning aspects of work and life is developed. Each aspect of the model affects the other aspects, so that debating and balancing the aspects is the main issue of interest for women. The findings of the study show that for an individual, opportunities for lifelong learning and meaningful work assure personal development, wellbeing at work and a sustainable career. The empirical data were drawn from interviews with 67 women who participated in training and coaching programmes in the South Savo region, Finland, in 2017-2021.

In Part B of the book, we discuss the methods and tools which can be used to support SG women in working life, developed in real-life cases in the three countries. At the level of individuals, the challenge for SG women lies in finding and applying the right strategy combining various components of their lives. They need tools (coaching, training, etc.) that outline the different possibilities and show positive alternatives to the social withdrawal strategy. At the level of employers, managers and HR professionals, there are various challenges in relation to SG women. Firstly, they are invisible, as most employees who are informal carers do not report this to the HR department. Secondly, it is important that SG women's jobs are flexible enough, allowing combination with caring tasks. Employers themselves will benefit from this: employers have every interest in motivating the older generation, the most experienced employees, to work for longer. At the level of career coaches, the challenge lies in the adequate guidance of women in the specific situation of the dual care task combined with a job.

The first chapter of Part B, 'Family Supportive Supervisors Behaviour for the Sandwich Generation: Considerations for Training Practice', by Miet Timmers 
and Tim Gielens, presents tools developed in the 'Sandwich Generation' Project in Flanders, with which SG members and their supervisors learn how to manage challenging situations at home and in the workplace. The chapter contains a brief literature study on Family Supportive Supervisor Behaviour (FSSB), highlighting the importance of family-friendly corporate policies and FSSB for the WSG. The chapter ends with a look at a self-assessment and learning tool designed for supervisors and recommendations for a family supportive corporative culture.

The second chapter of Part B by Dorota Kwiatkowska-Ciotucha and Urszula Załuska, 'Tools Developed in and Lessons Learned from the Time4Help Project in Poland', presents a description of model solutions developed in the Polish Project. The main attention is on the tools for the self-assessment of women in terms of their development needs and professional preferences.

Part B concludes with a chapter, 'Cases and Lessons Learned from the Time4Help Project in Finland', written by Kaija Villman and Mervi Rajahon$\mathrm{ka}$, describing cases and lessons learned from the Time4Help project in Finland. In the chapter, the authors describe a model for supporting mature women, developed as part of the Finnish Time4Help project. The model solution includes training mature women supporting their networking at work. The model is built on a novel training programme approach where first, women were asked to find a group of women who were interested in developing their enterprises or working skills and who had similar needs and interests to them, and after that, a training programme was built matching the needs of this particular group of women. Therefore, the authors build on the research literature on study circles, and study how women's networks can be used in order to enhance the lifelong learning of mature women, support their working life and help them to reach an appropriate work-life balance. The empirical part of the research builds on interviews and observations with 25 women participating in Time4Help training programmes and their facilitators in Finland in 2019-2021.

Part $\mathrm{C}$ of the book presents international comparative research based on a computer-assisted web interview (CAWI) survey on representative samples of people aged 45-65 in five European countries. The chapter 'Sandwich Generation in the Workplace - International Comparative Research' by Dorota Kwiatkowska-Ciotucha and Urszula Załuska discusses the assumptions and main conclusions from the research, the key purpose of which was to identify and characterise the representatives of the SG in selected European countries in relation to professional activity. The purpose was to gain data on people from the SG living in societies with diversified welfare state models, that is, Poland with its Central and Eastern European model, Finland with its social 
democratic model, Belgium with its conservative model, Great Britain with its liberal model and Italy with its Southern European model. The research was carried out in the autumn of 2020 with representative samples of Internet users aged 45-65. The results confirm the more extensive care burden of women in these countries, but also differentiation between the countries covered by the study. The intensity of the SG phenomenon ranged from $25 \%$ in Italy and $16 \%$ in Poland to $8-9 \%$ in Belgium or Finland and about $6 \%$ in Great Britain. The results prove that in countries with a high share of middleaged people in the SG group, the representatives of this group in the workplace are unrecognisable or even invisible.

In the concluding part of the book, we summarise the main results and draw conclusions on our research based on the viewpoints presented in the previous chapters. We present recommendations for employers, career coaches and policy-makers for supporting SG women in working life.

The book will be most interesting for people belonging to the SG and experts working in the field - practitioners, employers and policy-makers and postgraduate students in family studies.

\section{REFERENCES}

Abramson, T. A. (2015). Older adults: The "panini sandwich" generation. Clinical Gerontologist, 38(4), 251-267. https://doi.org/10.1080/07317115. 2015.1032466

Albertini, M. (2016). Ageing and family solidarity in Europe: Patterns and driving factors of intergenerational support. Policy Research Working Paper 7678, Poverty and Equity Global Practice Group, World Bank Group. Retrieved from https://openknowledge.worldbank.org/ bitstream/handle/10986/24516/Ageing0and0fam0generational0support. pdf? sequence $=1$

BBC News. (2020). Finland to give dads same parental leave as mums. Retrieved from https://www.bbc.com/news/world-europe-51384614 Bronselaer, J. (2016). De combinatie van mantelzorg met andere rollen. In J. Bronselaer, V. Vandezande, L. Vanden Boer, \& B. Demeyer (Eds.), Sporen naar duurzame mantelzorg. Hoe perspectief bieden aan mantelzorgers? (pp. 117-149). Brussel: Departement Welzijn, Volksgezondheid en Gezin. Retrieved from https://www.departementwvg.be/sites/default/files/med ia/2016_Sporen_naar_duurzame_mantelzorg_DWVG_0.pdf

Burke, R. J. (2017). The sandwich generation: individual, family, organizational and societal challenges and opportunities. In R. J. Burke \& 
L. M. Calvano (Eds.), The sandwich generation. Caring for oneself and others at home and at work (pp. 3-39). Cheltenham: Edward Elgar.

Chisholm, J. F. (1999). The sandwich generation. Journal of Social Distress and the Homeless, 8(3), 177-191.

Deloitte. (2017). Comparative social security benefits study. Retrieved from https://www2.deloitte.com/content/dam/Deloitte/be/Documents/tax/ TaxStudiesAndSurveys/Comparitive\%20Benefits\%20Study_2017.pdf

Denzin, N. K., \& Lincoln, Y. S. (Eds.). (2018). The Sage handbook of qualitative research (5th ed.). Thousand Oaks, CA: SAGE Publications, Inc.

Ebbinghaus, B. (2012, September 6-8). Comparing welfare state regimes: Are typologies an ideal or realistic strategy? [Paper presentation]. ESPAnet Conference, Edinburgh, UK. Retrieved from https://dokument.pub/welfarestate-regimes-are-an-ideal-or-realistic-strategy1-flipbook-pdf.html

Eikemo, T. A., Bambra, C., Joyce, K., \& Dahl, E. (2008). Welfare state regimes and income-related health inequalities: A comparison of 23 European countries. European Journal of Public Health, 18(6), 593-599. https://doi.org/10.1093/eurpub/ckn092

Emigh, R. J., Feliciano, C., O’Malley, C., \& Cook-Martín, D. (2018). The effect of state transfers on poverty in post-socialist Eastern Europe. Social Indicators Research, 138(2), 545-574. https://doi.org/10.1007/ s11205-017-1660-y

Esping-Andersen, G. (1990). The three worlds of welfare capitalism. Princeton, NJ: Princeton University Press.

European Commission. (2020). Employment and social developments in Europe 2020. Leaving no one behind and striving for more: Fairness and solidarity in the European social market economy. European Commission. Directorate-General for Employment, Social Affairs and Inclusion. Directorate A. Luxembourg: Publications Office of the European Union. Eurostat. (2021). Key figures on Europe 2021 edition. Luxembourg: Publications Office of the European Union.

Gesteland, R. R. (1999). Cross-cultural business behavior: Marketing, negotiating, and managing across cultures (2nd ed.). Copenhagen:

Copenhagen Business School Press.

Hofstede, G. (1980). Culture and organizations. International Studies of Management \& Organization, 10(4), 15-41. doi:10.1080/00208825.1980. 11656300 
Hofstede, G., Hofstede, G. J., \& Minkov, M. (2010). Cultures and organizations: Software of the mind intercultural cooperation and its importance for survival (3rd ed.). New York, NY: McGraw-Hill.

House, R. J., Hanges, P. J., Javidan, M., Dorfman, P. W., \& Gupta, V. (Eds.). (2004). Culture, leadership, and organizations: The GLOBE study of 62 societies. Thousand Oaks, CA: Sage Publications.

Miller, D. A. (1981). The "sandwich" generation: Adult children of the aging. Social Work, 26(5), 419-423.

Ollier-Malaterre, A. (2017). National context and employer-driven work-life policies. In R. J. Burke \& L. M. Calvano (Eds.), The sandwich generation. Caring for oneself and others at home and at work. (pp. 177-195). Cheltenham: Edward Elgar.

Parker, K., \& Patton, E. (2013). The sandwich generation: Rising financial burdens for middle-aged Americans. Retrieved from http://www.pewso cialtrends.org/2013/01/30/the-sandwich-generation/

Schwartz, S. H. (2012). An overview of the Schwartz theory of basic values. Online Readings in Psychology and Culture, 2(1), 11. doi:10.9707/2307-0919.1116

Silverstein, M., Tur-Sinai, A., \& Lewin-Epstein, N. (2020). Intergenerational support of older adults by the 'mature' sandwich generation: The relevance of national policy regimes. Theoretical Inquiries in Law, 21(1), 55-76. https://doi.org/10.1515/til-2020-0004.

Zamarro, G. (2020). Family labor participation and child care decisions: The role of grannies. SERIEs, 11, 287-312. https://doi.org/10.1007/ s13209-020-00213-5 